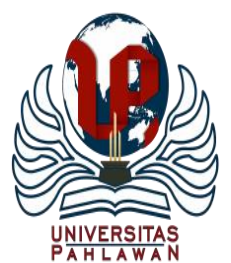

Edukatif : Jurnal Ilmu Pendidikan Volume 3 Nomor 6 Tahun 2021 Halm 3636 - 3646 EDUKATIF: JURNAL ILMU PENDIDIKAN

Research \& Learning in Education https://edukatif.org/index.php/edukatif/index

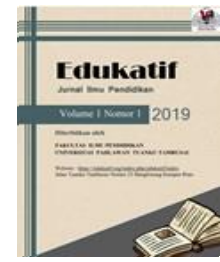

\title{
Analisis Kesesuaian Soal Penilaian Tengah Semester IPA dengan Kaidah Penyusunan Soal pada Aspek Bahasa di Sekolah Dasar
}

\author{
Ima Rahmawati ${ }^{1 凶}$, Yusuf Suryana ${ }^{2}$, Syarip Hidayat ${ }^{3}$
}

Universitas Pendidikan Indonesia, Indonesia, ${ }^{2,3}$

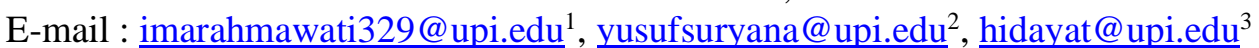

\begin{abstract}
Abstrak
Sekolah Dasar Negeri Galunggung merupakan sekolah dasar negeri di Kota Tasikmalaya yang memiliki skor standar penilaian dan standar tenaga pendidik tertinggi. Penelitian ini bertujuan mengungkap tingkat kesesuaian soal Penilaian Tengah Semester (PTS) IPA-yang dibuat guru SDN Galunggung-dengan kaidah penyusunan soal pilihan ganda pada aspek bahasa. Desain penelitian menggunakan analisis deskriptif dengan pendekatan kualitatif, metode studi kasus. Objek pada penelitian ini soal PTS IPA Kelas VI semester 1 TA 2020/2021, SDN Galunggung Kota Tasikmalaya, yang dipilih melalui sampel purposif. Sedangkan teknik pengumpulan data melalui pengumpulan data kualitatif; dokumen, observasi, wawancara. Adapun pengolahan data dilakukan dengan; reduksi, displai, dan analisis data, pendeskripsian hasil penelitian, lalu pembuatan kesimpulan. Hasil penelitian mengungkapkan bahwa soal PTS IPA yang berisi 25 soal ini sebesar $72 \%$ sesuai dengan kaidah bahasa Indonesia, 80\% sesuai dengan aturan penggunaan bahasa komunikatif, 96\% sesuai dengan aturan penggunaan frasa dalam pilihan jawaban, dan $100 \%$ sesuai dengan aturan penggunaan bahasa nasional dalam soal. Rata-rata persentase kesesuaian soal sebesar $87 \%$. Tingkat ketidaksesuaian soal hanya sebesar $13 \%$ yang secara umum terletak pada penerapan kaidah bahasa Indonesia (PUEBI) di dalam soal. Dengan begitu, secara keseluruhan soal PTS ini sudah sesuai dengan kaidah penyusunan soal pada aspek bahasa.
\end{abstract}

Kata Kunci: soal, PTS, kaidah bahasa.

\begin{abstract}
SDN Galunggung, a public elementary school in Tasikmalaya city with the highest standard of assessment and standards of educators. This study aims to reveal the level of conformity of the PTS IPA questions-made by SDN Galunggung teachers-with the rules of making multiple choice questions on language aspects. The research design uses descriptive analysis; qualitative approach; case study method. Research object: PTS IPA class VI semester 1 2020/2021 school year, SDN Galunggung Tasikmalaya, selected through a purposive sample. Data collection techniques through qualitative data collection; documents, observations, interviews. Data processing is carried out with; reduction, analysis, and analysis of data, decryption of research results, conclusion making. The results revealed, PTS IPA (contains 25 questions) $72 \%$ in accordance with Indonesian language rules, $80 \%$ use of communicative language, $96 \%$ of answer options use the right phrase, and $100 \%$ in accordance with the rules of use of the national language in the question. The average question compatibility percentage is $87 \%$. The level of non-conformity of the question is only $13 \%$ which generally lies in the application of Indonesian language rules (PUEBI) in the question. Thus, overall the PTS questions is in accordance with the rules of drafting questions on the language aspect.
\end{abstract}

Keywords: questions, midterm exam, language rules.

Copyright (c) 2021 Ima Rahmawati, Yusuf Suryana, Syarip Hidayat

$\square$ Corresponding author

Email : imarahmawati329@upi.edu

DOI $\quad$ : https://doi.org/10.31004/edukatif.v3i6.975 
3637 Analisis Kesesuaian Soal Penilaian Tengah Semester IPA dengan Kaidah Penyusunan Soal pada Aspek Bahasa di Sekolah Dasar - Ima Rahmawati, Yusuf Suryana, Syarip Hidayat

DOI: https://doi.org/10.31004/edukatif.v3i6.975

\section{PENDAHULUAN}

Pendidikan dikembangkan secara terus-menerus dalam upaya perbaikan kualitas pendidikan. Pembaharuan kurikulum merupakan bentuk dari upaya perbaikan tersebut, pembaharuannya meliputi aspek; muatan pendidikan, proses pembelajaran, penilaian (Retnawati, 2015:390). Kurikulum 2013 sebagai kurikulum pendidikan yang berjalan di Indonesia saat ini, memiliki karakteristik tersendiri. Salah satu karakteristik kurikulum 2013 yang menjadi pembeda dari kurikulum-kurikulum sebelumnya adalah proses pendidikannya yang holistik, yang berakibat pada proses penilaian yang harus holistik pula. Lebih lanjut, Setiadi (2016:167) menambahkan bahwa Kurikulum 2013 memiliki penilaian yang lebih tegas dan menyeluruh, yang ranah penilaiannya meliputi ranah kognitif, afektif, dan psikomotor.

Adanya perbedaan dalam aspek penilaian tersebut menghasilkan pembaharuan dalam sistem penilaian. Pembaharuan tersebut termuat dalam Permendikbud Nomor 23 Tahun 2016 Tentang Standar Penilaian. Salah satu ketentuan penilaian yang tercantum dalam peraturan tersebut adalah mengenai variasi alat ukur serta bentuk penilaian kognitif. Dijelaskan bahwa ada dua alat ukur untuk penilaian kognitif; tes dan non-tes. Setiap alat ukur tersebut memiliki variasi lagi dalam bentuk penilaiannya. Misalnya saja alat ukur tes yang memiliki dua bentuk penilaian; lisan dan tulis. Tes lisan dan tes tulis ini biasa digunakan dalam berbagai praktik penilaian seperti pada tes formatif, tes sumatif, tes diagnostik, tes seleksi dan penempatan.

Penilaian Tengah Semester sebagai bagian dari tes sumatif-yang diseleggarakan oleh pendidik terhadap peserta didik setelah melalui 8-9 minggu pembelajaran (Direktorat Pembinaan Sekolah Dasar, 2016:6) seringkali menggunakan tes tulis dalam pelaksanaannya. Bentuk tes tulis yang biasa digunakan diantaranya bentuk; objektif, esai, dan jawaban pendek, yang masing-masing memiliki variasinya lagi. Misalnya saja tes objektif memiliki variasi tes sebagai berikut; pilihan ganda, melengkapi, jawaban singkat, menjodohkan, dan salah-benar. Setiap bentuk tes tersebut memiliki ciri dan kegunaan yang berbeda. Oleh karenanya, guru harus bisa menentukan bentuk tes tulis seperti apa yang akan digunakan dalam proses penilaian didasarkan pada tujuan penilaiannya. Lebih lanjut, seorang guru dalam menyusun soal tes harus memahami terlebih dahulu kaidah-kaidah penyusunan soal tes. Dalam KBBI, kaidah artinya rumusan asas yang menjadi hukum; aturan yang sudah pasti; patokan. Kaidah penyusunan soal berarti rumusan asas berisi aturan pasti yang dijadikan dasar atau pedoman dalam menyusun soal. Keberadaan kaidah penyusunan soal adalah untuk menjaga kualitas soal agar dapat menjalankan fungsi pengukurannya dengan baik; mengukur apa yang ingin diukur. Maksudnya, soal atau tes harus mampu menjalankan fungsinya dalam hal mengukur kemampuan peserta didik dengan sebenar-benarnya (Hayati \& Mardapi, 2014:27). Suatu soal atau tes harus dapat mengukur ketercapaian tujuan pembelajaran peserta didik (Isnaeni, dkk., 2020). Hasil pengukuran yang tepat ini nantinya dapat dijadikan acuan dalam membuat keputusan terkait dengan pelaksanaan pendidikan.

Melihat betapa pentingnya fungsi penilaian dalam pendidikan, kiranya harus menjadi perhatian setiap guru untuk menghasilkan soal yang berkualitas, salah satunya yang sesuai dengan kaidah penyusunan soal; baik dalam aspek materi, konstruksi, maupun bahasa soal. Namun beberapa fakta di lapangan menunjukkan hal yang tidak sesuai dengan harapan. Misalnya saja dalam penelitian Syahriandi (2017:178-180) mengungkapkan bahwa soal ujian Bahasa Indonesia pada semester ganjil yang dibuat oleh guru kelas VI SDN Seuriget masih belum sempurna dari segi bahasa soal. Dari 25 soal pilihan ganda, sebanyak 8 soal tidak sesuai dengan penggunaan kaidah bahasa Indonesia. Ketidaksesuaiannya secara umum pada penggunaan huruf kapital, tanda baca, kata berimbuhan, dan pada pemilihan diksi. Kemudian sebaran angket oleh Nurdin (2019:274-276) terhadap 27 guru MIN Sabang serta studi dokumentasi dan wawancara terhadap 6 guru (kelas 1 s.d. 6) MIN Sabang menemukan beberapa ketidaksesuaian dalam soal UAS. Ditemukan beberapa soal tidak komunikatif dan tidak menggunakan bahasa baku (seperti dalam penggunaan huruf kapital, tanda baca, imbuhan, dan ejaan). Sedangkan penelitian yang dilakukan oleh Wuryanti S. dan Muhardis (2020:340-344) menunjukkan instrumen soal yang digunakan guru di salah satu sekolah dalam kegiatan PTS belum sesuai 
dengan kaidah penyusunan soal, seperti tidak adanya homogenitas dalam pilihan jawaban dan panjangpendeknya pilihan jawaban tidak relatif sama. Dalam aspek bahasa, ketidaksesuaiannya pada penggunaan frasa yang bukan satu kesatuan pengertian secara berulang. Fakta-fakta tersebut menunjukkan masih banyaknya permasalahan seputar penyusunan soal dalam aspek bahasa. Artinya, masih banyak sekali permasalahan-permasalahan yang dialami guru sekolah dasar dalam menghasilkan soal-soal yang berkualitas.

Disamping permasalahan seputar penyusunan soal tes di atas, peneliti menemukan suatu fakta di SDN Galunggung Kota Tasikmalaya, dimana SDN Galunggung menjadi satu-satunya sekolah dasar di Kota Tasikmalaya yang memiliki standar penilaian yang mencapai angka 100, kemudian skor tenaga pendidiknya yang mencapai angka 95, hal ini ditemukan dalam data akreditasi terbaru yang dikeluarkan oleh BAN-S/M. Seperti yang kita ketahui bahwa kegiatan akreditasi sekolah adalah proses penilaian secara komprehensif terhadap kelayakan satuan program pendidikan yang diterbitan oleh lembaga mandiri. Fakta lainnya berdasarkan hasil wawancara terungkap bahwa guru di SDN Galunggung selalu melakukan proses penyusunan soal secara mandiri, terutama dalam kegiatan penilaian yang dielenggarakan oleh pendidik seperti Penilaian Harian, Penilaian Tengah Semester, dan Penilaian Akhir Semester. Berlandaskan pada kedua fakta tersebut, peneliti berasumsi bahwa guru-guru di SDN Galunggung adalah guru-guru yang berkompeten dalam menghasilkan soal yang berkualitas. Peneliti berasumsi bahwa soal yang digunakan dalam kegiatan penilaian seperti dalam Penilaian Tengah Semester adalah soal-soal yang berkualitas, yang sesuai dengan kaidah penyusunan soal, baik dari segi materi, konstruksi maupun bahasa.

Didasarkan pada fakta-fakta tersebut, peneliti melakukan penelitian terhadap soal PTS IPA di kelas VI SDN Galunggung (semester 1 TA 2020/2021) dengan judul "Analisis Kesesuaian Soal Penilaian Tengah Semester IPA dengan Kaidah Penyusunan Soal pada Aspek Bahasa, di Sekolah Dasar". Penelitian ini bertujuan untuk mengungkap seberapa besar kesesuaian soal PTS yang dibuat oleh guru kelas VI SDN Galunggung dengan kaidah penyusunan soal aspek bahasa. Berbeda dengan penelitian Wuryanti dan Muhardis, analisis soal PTS kali ini tidak dilakukan terhadap semua aspek kaidah penyusunan soal, namun hanya dikhususkan pada aspek bahasa soal karena didasarkan pada hasil temuan peneliti-peneliti sebelumnya yang mengungkapkan banyaknya permasalahan seputar penggunaan kaidah bahasa soal di dalam penyusunan soal. Penelitian ini diharapkan dapat meningkatkan kesadaran para guru, bahwa untuk menghasilkan soal yang berkualitas harus dimulai dari hal terkecil; menerapkan kaidah penggunaan bahasa dalam penyusunan soal. Sehingga apabila kualitas suatu penilaian terjamin, maka selanjutnya kualitas suatu pendidikan akan terjamin pula.

\section{METODE PENELITIAN}

Penelitian ini dilaksanakan dengan desain analisis deskriptif, menggunakan pendekatan kualitatif. Adapun metode yang digunakan dalam penelitian ini metode studi kasus. Objek yang diteliti pada penelitian ini adalah soal penilaian tengah semester (PTS) IPA kelas enam semester I Tahun Ajar 2020/2021, yang dibuat dan digunakan oleh SDN Galunggung, Kota Tasikmalaya. Penentuan objek penelitian (yang sekaligus menjadi sampel penelitian) dilakukan melalui teknik sampel purposif, dengan didasarkan pada pertimbangan; kebaharuan informasi dan kelengkapan informasi. Adapun informasi mengenai kebaruan dan kelengkapan data didapat dari hasil wawancara studi pendahuluan terhadap guru kelas 4-6 SDN Galunggung. Penelitian yang diselenggarakan di SDN Galunggung Kota Tasikmalaya ini melalui proses penelitian selama kuranglebih 14 hari.

Instrumen yang digunakan pada penelitian ini ada dua, diantaranya pedoman dan lembar observasi "Kaidah Penyusunan Soal Pilihan Ganda pada Aspek Bahasa", serta pedoman wawancara terhadap guru. Dalam proses pengumpulan data, ada tiga teknik yang digunakan; a) pengumpulan dokumen kualitatif, yaitu dokumen soal PTS IPA kelas enam, b) observasi kualitatif terhadap soal, dan c) wawancara terbuka semi 
3639 Analisis Kesesuaian Soal Penilaian Tengah Semester IPA dengan Kaidah Penyusunan Soal pada Aspek Bahasa di Sekolah Dasar - Ima Rahmawati, Yusuf Suryana, Syarip Hidayat

DOI: https://doi.org/10.31004/edukatif.v3i6.975

terstruktur terhadap guru kelas 4-6 SDN Galunggung. Sedangkan dalam proses pengolahan atau analisis data, dilaksanakan berdasarkan teknik penelitian kualitatif Strauss \& Corbin (2003) dengan melalui beberapa tahap; 1) mereduksi data; data yang direduksi diantaranya data hasil wawancara dan hasil studi dokumentasi 2) mendisplai data; menghasilkan data utama untuk kemudian dianalisis, yaitu soal PTS kelas enam semester 1 TA 2020/2021, 3) menganalisis data, prosesnya; menganalisis kesesuaian setiap butir soal dengan indikatorindikator kaidah penyusunan soal PG aspek bahasa, lalu membuat tanda ceklis (v) pada kolom "Ya" jika soal memenuhi indikator dan tanda silang (x) pada kolom "Tidak" jika soal tidak memenuhi indikator, 4) mendeskripsikan hasil penelitian; menguraikan letak ketidaksesuaian secara deskripsi serta memaparkan bentuk yang lebih sesuai, kemudian membuat persentase kesesuaian dan persentase ketidaksesuaian soal melalui bentuk persentase sederhana, 5) membuat kesimpulan yang didasarkan pada hasil persentase yang ditunjukkan. Semakin besar nilai persentase yang ditunjukkan menandakan semakin tinggi tingkat kesesuaian soal-soal tersebut dengan kaidah penyusunan soal PG dalam aspek bahasa.

\section{HASIL DAN PEMBAHASAN PENELITIAN}

Soal PTS yang menjadi objek analisis dalam penelitian ini memiliki karakteristik bentuk soal berupa pilihan ganda (PG)-soal pilihan ganda menjadi soal yang paling banyak digunakan oleh guru dalam pelaksanaan kegiatan PTS (Choirunisa et al., 2021:3) -. Kemudian karakteristik selanjutnya, soal PTS ini berisikan sebanyak 25 soal dan setiap soal memiliki empat opsi atau empat pilihan jawaban. Dalam hal ini, kegiatan analisis soal didasarkan pada kaidah penyusunan soal pilihan ganda dalam aspek bahasa, dengan indikator analisis sebagai berikut; 1) Setiap soal harus menggunakan bahasa yang sesuai dengan kaidah bahasa Indonesia, 2) Jangan menggunakan bahasa yang berlaku setempat jika soal akan digunakan secara nasional, 3) Setiap soal harus menggunakan bahasa yang komunikatif, 4) Pilihan jawaban jangan mengulang kata atau frasa yang bukan satu kesatuan pengertian (Pusat Penilaian Pendidikan, 2017:12).

Dari hasil analisis ditemukan beberapa ketidaksesuaian dalam penyusunan soal PTS tersebut. Pada indikator pertama, sebanyak tujuh soal tidak memenuhi kaidah penyusunan soal; soal nomor 1, 7, 9. 11, 21, 22, dan soal nomor 23. Pada indikator ke-dua, tidak ditemukan kesalahan dalam penyusunan soal. Pada indikator ke-tiga, sebanyak lima soal tidak memenuhi kaidah; soal nomor 2, 3, 4, 9, dan 11. Dan terakhir, pada indikator ke-empat terdapat satu soal yang tidak memenuhi kaidah, yaitu soal nomor 23.

Berikut pemaparan secara lebih lanjut atas hasil temuan yang telah didapat di atas disertai lampiran dokumen soal;

\section{Soal Harus Sesuai dengan Kaidah Bahasa Soal}

Badan Pengembangan dan Pembinaan Bahasa menjelaskan bahwa acuan yang digunakan bagi penutur bahasa Indonesia dalam pemakaian bahasa tulis secara baik dan benar adalah Pedoman Umum Ejaan Bahasa Indonesia (PUEBI). PUEBI berisi kaidah-kaidah kebahasaan yang berkaitan dengan; pemakaian huruf, penulisan kata, pemakaian tanda baca, dan penulisan unsur serapan.

Ketidaktepatan pada pemakaian huruf ada pada soal nomor 21. Salah satu pilihan jawaban pada soal nomor 21 merupakan kata asing "traffic light". Dalam kaidah penulisan bahasa Indonesia, kata asing harusnya ditulis menggunakan huruf miring, sedangkan pada soal tersebut yang digunakan huruf tegak.

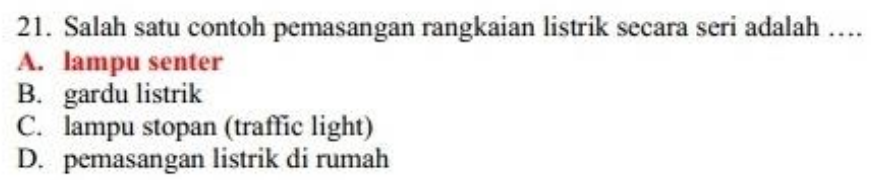

Gambar 1 : Soal nomor 21 
3640 Analisis Kesesuaian Soal Penilaian Tengah Semester IPA dengan Kaidah Penyusunan Soal pada Aspek Bahasa di Sekolah Dasar - Ima Rahmawati, Yusuf Suryana, Syarip Hidayat

DOI: https://doi.org/10.31004/edukatif.v3i6.975

Kemudian, ketidaktepatan dalam penulisan kata ada pada soal nomor 1, 9 dan 22. Pada soal nomor satu, terdapat kata "berkembangbiak". Kata tersebut merupakan kata tidak baku. Penggunaan kata yang lebih tepat adalah kata "berkembangbiak", yang dibangun atas gabungan kata padu kembangbiak yang diberi prefiks ber. Pada soal nomor sembilan juga terdapat kata tidak baku "Nasionl" dan "Nasinal", kata yang lebih tepat adalah "Nasional". Pada soal nomor 22, ketidaktepatan lebih kepada penggunaan diksi dan penggunaan kata tidak baku. Kata "pengantar" kurang tepat digunakan pada topik arus listrik. Kata "pengantar" berasal dari kata dasar antar yang memiliki arti bawa dan kirim. Kata yang lebih tepat digunakan adalah kata "penghantar" yang berasal dari kata dasar hantar berprefiks peng-, yang memiliki arti penerus dan penyalur. Kemudian kata "liatrik" yang ada pada salah satu pilihan jawaban merupakan kata yang tidak baku dan tidak memiliki makna. Kata yang seharusnya digunakan adalah kata "listrik".

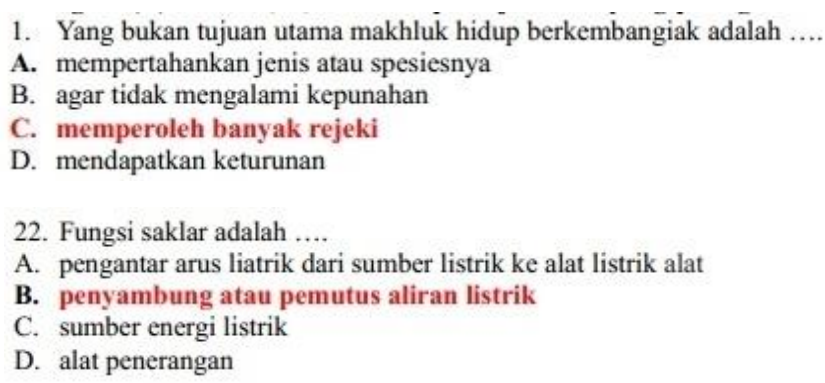

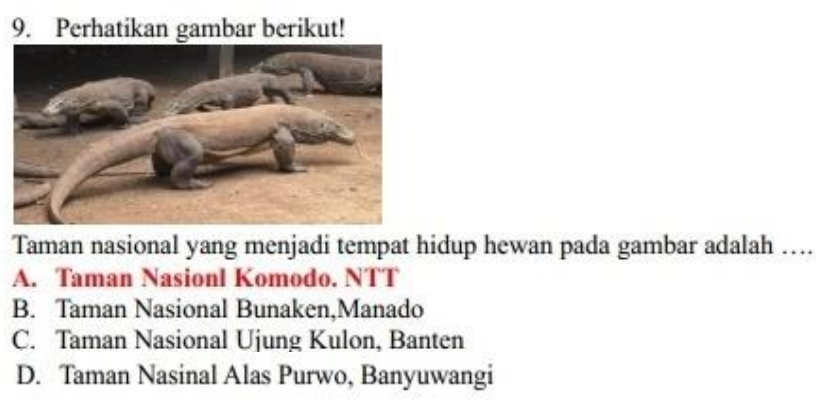

Gambar 2 : Soal nomor 1, 99, dan 22

Setiap soal harus disusun dengan menggunakan bahasa baku, karena bahasa yang baku dapat menyatukan semua penutur dari berbagai dialek bahasa (Moeliono, dkk., 2017:13). Dalam hal ini, penggunaan bahasa baku dalam soal akan memudahkan peserta didik memahami soal tidak perduli dari mana peserta didik berasal dan bagaimana ragam dialek yang dimiliki para peserta didik. Sumarwati, Anindyarini, \& Fuady (2014:104) menjelaskan bahwa bahasa yang baik adalah yang menyesuaikan situasi, dan bahasa yang benar adalah yang sesuai kaidah. Ketika ada dalam situasi resmi, maka sudah seharusnya bahasa yang digunakan bahasa baku. Dalam hal ini, kegiatan penilaian tengah semester merupakan sesuatu yang ada dalam situasi resmi. Oleh karenanya, penggunaan bahasa tidak baku di dalam soal harus dihindari.

Selanjutnya pada pemakaian tanda baca, letak ketidaksesuaian ada pada soal nomor 7, 9, 11 dan 23 . Pada soal nomor 7, letak ketidaksesuaian ada pada tidak digunakannya tanda koma (,) pada salah satu pilihan jawaban. Dalam kaidah bahasa Indonesia, tanda koma harus disertakan pada kalimat majemuk setara yang diletakkan sebelum konjungsi (Mustakim et al., 2016:40). Kalimat pada pilihan jawaban tersebut seharusnya menyertakan tanda koma sebelum konjungsi "kemudian". Selain digunakan pada kalimat majemuk setara, tanda koma juga digunakan sebagai pemisah antara nama tempat dan wilayah (Mustakim et al., 2016:42). Hal ini pula yang menjadi titik kesalahan soal nomor 9 yang tidak membubuhkan tanda koma pada salah satu pilihan jawaban. Pada pilihan jawaban tersebut, harusnya membubuhkan tanda koma sebagai berikut "Taman Nasional Komodo, NTT", karena terdapat nama tempat dan wilayah yang harus dipisahkan oleh tanda tersebut (tanda koma). Soal nomor 11 kurang sesuai sebab tanda yang digunakan untuk menyambung unsur kata ulang "terus-menerus" pada soal tersebut adalah tanda pisah. Tanda baca yang seharusnya digunakan adalah tanda hubung (-). Sedangkan soal nomor 23 kurang sesuai sebab bentuk soal nomor 23 merupakan bentuk pertanyaan langsung, bukan bentuk melengkapi. Tanda baca yang tepat untuk mengakhiri pertanyaan adalah tanda tanya (?), bukan tanda elipsis empat. 
3641 Analisis Kesesuaian Soal Penilaian Tengah Semester IPA dengan Kaidah Penyusunan Soal pada Aspek Bahasa di Sekolah Dasar - Ima Rahmawati, Yusuf Suryana, Syarip Hidayat

DOI: https://doi.org/10.31004/edukatif.v3i6.975

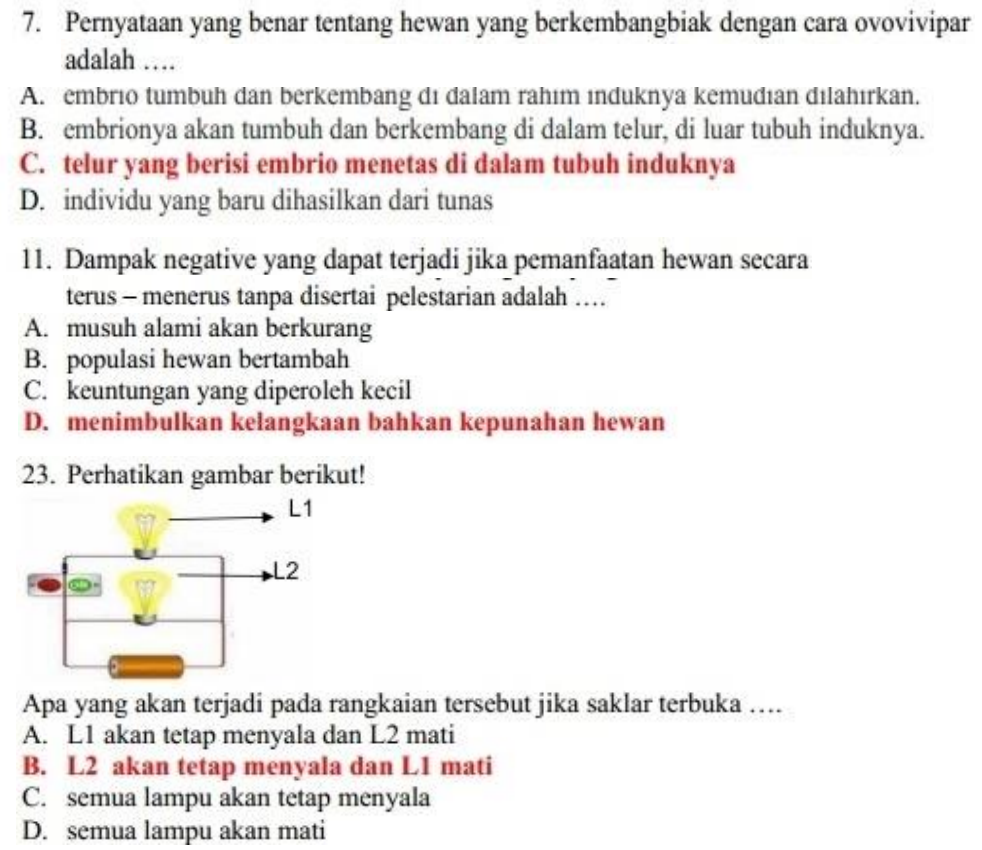

Gambar 3 : Soal nomor 7, 11, dan 23

Terakhir, ketidaktepatan dalam penulisan unsur serapan ada pada soal nomor sebelas. Pada soal nomor 11, terdapat penggunaan kata "negative". Kata "negative" merupakan kata dari bahasa Inggris. Kata serapan dari kata "negative" adalah "negatif", sebab kaidah bahasa Indonesia menjelaskan bentuk serapan dari kata asing berkahiran -ive adalah dengan mengubahnya menjadi bentuk -if (Mustakim et al., 2016:74).

\section{Jangan Menggunakan Bahasa yang Berlaku Setempat jika Soal Digunakan secara Nasional}

Soal yang diperuntukkan secara nasional harus menggunakan bahasa nasional. Penggunaan bahasa tertentu-misalnya bahasa daerah-di dalam soal boleh jikalau soal memang tidak diperuntukkan secara nasional, hanya diperuntukkan untuk daerah tertentu saja yang menggunakan bahasa tersebut. Dari hasil analisis, ke-25 soal PTS IPA yang dibuat oleh guru kelas enam SDN Galunggung semuanya menggunakan bahasa nasional, tidak ditemukan penggunaan bahasa tertentu seperti bahasa daerah walaupun soal yang dibuat ini hanya diperuntukkan untuk sekolah tersebut saja.

\section{Soal Harus Menggunakan Bahasa yang Komunikatif}

Bahasa yang komunikatif adalah bahasa yang mudah dipahami atau dimengerti oleh kedua belah pihak dalam suatu tuturan (Suwartono \& Hidayat, 2016:13). Agar informasi atau suatu gagasan lebih mudah dipahami, maka dalam suatu tuturan baik lisan maupun tulis harus menerapkan tata bahasa yang baik dan benar. Tata bahasa sendiri berkenaan dengan kaidah atau patokan umum dalam berbahasa yang didasarkan pada struktur bahasa, meliputi; fonologi (tata bunyi), morfologi (tata bentuk), dan sintaksis (tata kalimat) (Prihanti, 2015 :2). Dalam hal ini, tata bahasa yang digunakan dalam penulisan soal lebih difokuskan pada tata bentuk (morfem dan kata) dan tata kalimat (frasa, klausa, dan kalimat).

Dari analisis yang dilakukan, terdapat lima soal yang dinilai kurang komunikatif dalam penulisannya karena kurang sesuai dengan tata bahasa yang ada. Secara umum ketidaksesusaian soal nomor 2, 3, dan 11 terletak pada penggunaan moferm atau kata. Sedangkan untuk soal nomor 4 dan 9, ketidaksesuaian terletak pada penggunaan frasa. Berikut penjelasannya: 
Soal nomor 2 menggunakan kata "adalah" dalam mengakhiri kalimat pertanyaannya. Kata tersebut kurang pas jika melihat pada jenis kalimat soal yang berupa kalimat pasif, sedangkan kata "adalah" biasanya digunakan pada kalimat aktif yang berkedudukan sebagai predikat dan diletakkan setelah subjek. Selain itu penggunaan kata "adalah" pada soal ini menjadi kurang pas karena melihat bentuk jawabannya yang berupa nomina, bukan berbentuk uraian penjelasan maupun rincian. Kata yang lebih tepat yang bisa digunakan sebagai pengganti "adalah" pada soal tersebut namun tetap sepadan dari segi tujuan adalah kata "dinamakan".

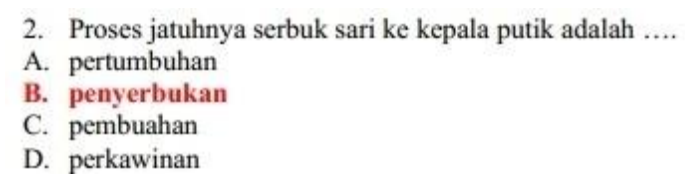

Gambar 4 : soal nomor 2

Soal nomor 3 kesalahannya yaitu tidak digunakannya kata hubung (konjungsi) antara dua frasa pada kalimat soal, sehingga menyebabkan makna soal menjadi rancu. Konjungsi yang harusnya ada dari soal tersebut adalah konjungsi "sebagai", sehingga kalimat soal menjadi "Bagian bunga yang berfungsi sebagai alat reproduksi betina ditunjukkan pada nomor....".

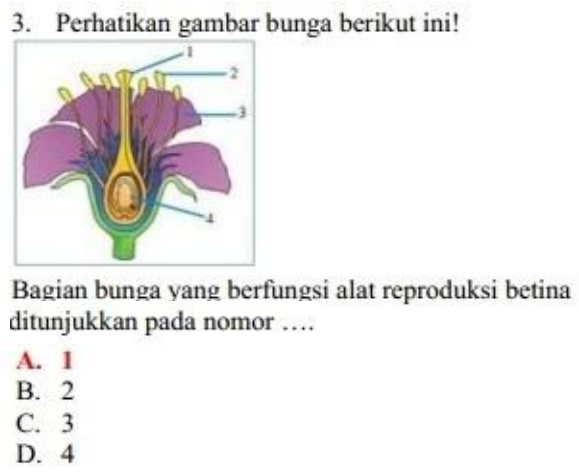

Gambar 5 : Soal nomor 3

Sama hal nya dengan soal nomor satu, kekurangtepatan soal nomor 4 juga pada penggunaan kata "adalah" dalam mengakhiri kalimat pertanyaan. Soal nomor empat memiliki bentuk jawaban berupa gambar. Agar menunjukkan maksud soal secara langsung, kata "adalah" dapat diganti dengan frasa "ditunjukkan oleh gambar", sehingga bentuk kalimatnya menjadi "Proses jatuhnya serbuk sari ke kepala putik pada bunga yang sama ditunjukkan oleh gambar....".

4. Proses jatuhnya serbuk sari ke kepala putik pada bunga yang

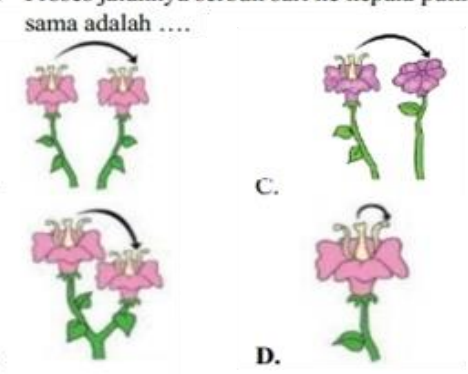

Gambar 6 : Soal nomor 4 
3643 Analisis Kesesuaian Soal Penilaian Tengah Semester IPA dengan Kaidah Penyusunan Soal pada Aspek Bahasa di Sekolah Dasar - Ima Rahmawati, Yusuf Suryana, Syarip Hidayat

DOI: https://doi.org/10.31004/edukatif.v3i6.975

Soal nomor 9 memanfaatkan stimulus (berupa gambar) untuk menjelaskan maksud soal, yang diletakkan di bagian atas sebelum kalimat soal. Namun pada situasi kali ini, stimulus tersebut menjadi kurang efektif akibat penggunaan akhiran kalimat soal yang kurang tepat. Situasi ini membawa pada soal yang kurang komunikatif. Penyertaan kata depan "di" dan kata "atas" akan lebih menunjukkan maksud soal secara langsung. Hal ini berhubungan dengan kedudukan kata tersebut (kata "di") sebagai afiks atau morfem terikat, yang mana morfem ini menjadi penyebab munculnya makna gramatikal (Gani \& Arsyad, 2018:8). Dengan demikian, pertanyaannya menjadi "Perhatikan gambar berikut! Taman nasional yang menjadi tempat hidup hewan pada gambar di atas adalah....".

Soal nomor 11 menjadi kurang komunikatif karena hilangnya kata tertentu dalam kalimat soal sehingga soal terasa ganjil. Penambahan kata "dilakukan" pada kata "hewan" dan konjungsi "secara" akan lebih memperjelas maksud soal, sehingga kalimat soal menjadi "Dampak negatif yang dapat terjadi jika pemanfaatan hewan dilakukan secara terus-menerus tanpa disertai pelestarian adalah....”.

Berdasarkan hal tersebut, guru sebagai penyusun soal kiranya lebih cermat dalam menggunakan bahasa. Kecermatan dalam penggunaan bahasa akan menjamin informasi atau maksud yang ingin disampaikan dimengerti oleh si penerima informasi dengan tepat (Hemandra, dkk., 2017:45) (Warsiman, 2020:2).

\section{Pilihan Jawaban jangan Mengulang Kata yang Bukan Satu Kesatuan Pengertian}

Pilihan jawaban yang mengulang kata atau frasa yang bukan satu kesatuan pengertian akan menyebabkan kekurang efektifan waktu dalam menjawab soal. Berdasarkan hasil analisis pada 25 soal yang ada, hanya ditemukan satu soal yang dalam pilihan jawabannya terdapat pengulangan frasa bukan satu kesatuan pengertian, yaitu soal nomor 23 yang pengulangannya pada pilihan jawaban A. dan B. (pada frasa "Lx akan tetap menyala dan Ly akan mati") dan pada pilihan jawaban C. dan D. (pada frasa "semua lampu akan..."). Cara menyusun soal agar tidak mengulang frasa yang bukan satu kesatuan pengertian adalah dengan memasukkan frasa yang sama tersebut ke dalam pokok soal (Pusat Penilaian Pendidikan, 2017:29). Dengan begitu, bentuk soal dan jawaban yang lebih baik sebagai berikut:

23. Yang akan terjadi pada rangkaian tersebut jika saklar terbuka adalah $\mathrm{L} 1$.... dan L2 .....
A. menyala; mati
B. mati; menyala
C. menyala; menyala
D. mati; mati

Berdasarkan temuan-temun tersebut, diperoleh persentase ketidaksesuaian soal dengan kaidah penyusunan soal yang dirincikan dalam tabel sebagai berikut:

Tabel 1. Persentase Ketidaksesuaian Soal PTS IPA Kelas VI SDN Galunggung dengan Kaidah Penyusunan Soal PG pada Aspek Bahasa

\begin{tabular}{llll}
\hline \multicolumn{1}{c}{ Indikator } & \multicolumn{1}{c}{ Butir Soal } & Total Butir Soal & \multicolumn{1}{c}{$\begin{array}{c}\text { Persentase } \\
(\%)\end{array}$} \\
\hline $\begin{array}{l}\text { Setiap soal harus menggunakan bahasa yang } \\
\text { sesuai dengan kaidah bahasa Indonesia }\end{array}$ & $1,7,9,11,21,22$, & 7 soal & $28 \%$ \\
\hline $\begin{array}{l}\text { Jangan menggunakan bahasa yang berlaku } \\
\text { setempat jika soal akan digunakan secara } \\
\text { nasional }\end{array}$ & 23 & 0 soal & $0 \%$ \\
\hline $\begin{array}{l}\text { Setiap soal harus menggunakan bahasa yang } \\
\text { komunikatif }\end{array}$ & $2,3,4,9,11$ & 5 soal & $20 \%$ \\
\hline
\end{tabular}


3644 Analisis Kesesuaian Soal Penilaian Tengah Semester IPA dengan Kaidah Penyusunan Soal pada Aspek Bahasa di Sekolah Dasar - Ima Rahmawati, Yusuf Suryana, Syarip Hidayat

DOI: https://doi.org/10.31004/edukatif.v3i6.975

\begin{tabular}{lcc}
\hline $\begin{array}{l}\text { Pilihan jawaban jangan mengulang kata atau } \\
\text { frasa yang bukan satu kesatuan pengertian }\end{array}$ & 23 & 1 soal \\
\hline Total Persentase Ketidaksesuaian & & $4 \%$ \\
\hline Rata-rata Persentase Ketidaksesuaian & $\mathbf{5 2 \%}$ \\
\hline
\end{tabular}

Dari Tabel $1 \mathrm{di}$ atas, kita dapat mengetahui tingkat ketidaksesuaian soal-soal tersebut dengan kaidah bahasa soal, yang mana ketidaksesuaian dengan indikator pertama sebesar 28\%, ketidaksesuaian dengan indikator-2 sebesar $0 \%$, ketidaksesuaian dengan indikator-3 sebesar 20\%, dan ketidaksesuaian dengan indikator-4 sebesar 4\%. Data ini memperlihatkan bahwa tingkat ketidaksesuaian tertinggi ada pada indikator pertama, sedangkan tingkat ketidaksesuaian terkecil ada pada indikator ke-dua. Rata-rata persentase ketidaksesuaian yang dihasilkan menunjukkan bahwa hanya sebagian kecil ketidaksesuaian yang ada pada soal, yaitu sebesar $13 \%$ dari $100 \%$

Untuk melakukan perbandingan, berikut data persentase kesesuaian soal dengan kaidah penyusunan soal yang disajikan dalam tabel berikut:

Tabel 2. Persentase Kesesuaian Soal PTS IPA Kelas VI SDN Galunggung dengan Kaidah Penyusunan Soal PG pada Aspek Bahasa

\begin{tabular}{|c|c|c|c|}
\hline Indikator & Butir Soal & Total Butir Soal & $\begin{array}{l}\text { Persentase } \\
\quad(\%)\end{array}$ \\
\hline $\begin{array}{l}\text { Setiap soal harus menggunakan bahasa yang } \\
\text { sesuai dengan kaidah bahasa Indonesia }\end{array}$ & $\begin{array}{l}2,3,4,5,6,8,10 \\
12,13,14,15,16 \\
17,18,19,20,24 \\
25\end{array}$ & 18 soal & $72 \%$ \\
\hline $\begin{array}{l}\text { Jangan menggunakan bahasa yang berlaku } \\
\text { setempat jika soal akan digunakan secara } \\
\text { nasional }\end{array}$ & $1-25$ & 25 soal & $100 \%$ \\
\hline $\begin{array}{l}\text { Setiap soal harus menggunakan bahasa yang } \\
\text { komunikatif }\end{array}$ & $\begin{array}{l}1,5,6,7,8,10,12, \\
13,14,15,16,17, \\
18,19,20,21,22, \\
23,24,25\end{array}$ & 20 soal & $80 \%$ \\
\hline $\begin{array}{l}\text { Pilihan jawaban jangan mengulang kata atau } \\
\text { frasa yang bukan satu kesatuan pengertian }\end{array}$ & $1-22,24,25$ & 24 soal & $96 \%$ \\
\hline Total Persentase Ketidaksesuaian & & & $348 \%$ \\
\hline Rata-rata Persentase Ketidaksesuaian & & & $87 \%$ \\
\hline
\end{tabular}

Dari Tabel 2 di atas dapat kita lihat bahwa sebanyak 72\% soal sudah sesuai dengan kaidah bahasa Indonesia. Kemudian, sebanyak $80 \%$ sudah menggunakan bahasa yang komunikatif dalam soal, dan sebanyak 96\% pilihan jawaban sudah dibuatkan tanpa mengulang frasa yang bukan satu kesatuan pengertian. Persentase kesesuaian tertinggi yaitu dengan indikator dua, sebanyak 100\%-yang mana artinya tidak ada kesalahan dari ke-25 soal tersebut dalam penggunaan jenis bahasa.

Dengan persentase pada masing-masing indikator tersebut, didapatkan persentase secara keseluruhan. Persentase keseluruhan menunjukkan bahwa soal PTS IPA kelas VI SDN Galunggung, semester 1 Tahun Ajar 2020/2021, memiliki tingkat kesesuaian sebesar 87\% dengan kaidah penyusunan soal PG aspek bahasa. Artinya, hanya 13\% saja ketidaksesuaian soal dengan kaidah penyusunan soal. Dengan persentase keseluruhan tersebut, maka dapat dikatakan bahwa soal secara umum sudah memenuhi kaidah penyusunan soal pada aspek bahasa. Hasil penelitian yang didapat ini memiliki kesamaan dengan hasil penelitian yang dilakukan oleh Gimo \& Farida (2019:35), dimana hasil penelitian sama-sama menunjukkan besaran ketidaksesuaian tertinggi ada pada penggunaan kaidah bahasa Indonesia. Sementara itu di tempat ke-dua ada pada penggunaan bahasa komunikatif, lalu di tempat ke-tiga pada pengulangan frasa yang bukan satu kesatuan pengertian. 
3645 Analisis Kesesuaian Soal Penilaian Tengah Semester IPA dengan Kaidah Penyusunan Soal pada Aspek Bahasa di Sekolah Dasar - Ima Rahmawati, Yusuf Suryana, Syarip Hidayat

DOI: https://doi.org/10.31004/edukatif.v3i6.975

Perbedaannya, penelitian Gimo dan Farida tidak menunjukkan bagaimana penggunaan bahasa nasional dalam soal.

Keterbatasan pada penelitian ini terletak pada proses verifikasi hasil temuan yang hanya dilakukan oleh peneliti sendiri. Dengan begitu, pada sebagian kecil hasil temuan terdapat kemungkinan adanya subjektifitas yang tidak dapat dihindarkan. Namun begitu, dengan adanya hasil penelitian-yang menunjukkan hasil yang positif-ini diharapkan dapat meningkatkan peran guru di sekolah dasar lainnya untuk melaksanakan perannya secara lebih lagi di dalam proses penilaian pendidikan. Sebagaimana yang disampaikan oleh Arifin (2012) (Nisa \& Pahlevi, 2021:2147) bahwa guru memiliki peran yang krusial dalam melaksanakan proses pembelajaran, termasuk di dalamnya dalam pelaksanaan evaluasi hasil belajar peserta didik. Oleh karena itu dalam hal ini besar-tidaknya peran seorang guru dalam menghasilkan soal yang baik akan berdampak pada kualitas suatu penilaian, dan pada akhirnya akan membawa dampak pada kualitas pendidikan juga.

\section{KESIMPULAN}

Dari hasil analisis yang didapat, diperoleh suatu kesimpulan bahwa soal PTS IPA kelas VI yang dibuat dan digunakan pada kegiatan PTS semester 1 Tahun Ajar 2020/2021 dapat dikatakan sudah memenuhi kaidah penyusunan soal pilihan ganda pada aspek bahasa. Hasil ini juga dapat menjawab asumsi di awal, bahwa guruguru di SDN Galunggung adalah guru-guru yang cukup berkompeten dalam menghasilkan soal yang baik. Soal yang digunakan dalam kegiatan Penilaian Tengah Semester termasuk soal-soal yang berkualitas, yang sesuai dengan kaidah bahasa penyusunan soal. Penemuan yang didapat ini memiliki perbedaan dengan penemuan-penemuan sebelumnya yang mengatakan bahwa soal-soal yang dibuat oleh guru SD untuk diujikan kepada peserta didik banyak memiliki ketidaksesuaian dengan kaidah penyusunan soal, khususnya pada aspek bahasa.

\section{UCAPAN TERIMA KASIH}

Penulis mengucapkan terimakasih kepada pihak yang telah terlibat langsung dalam penelitian ini-SDN Galunggung Kota Tasikmalaya. Peneliti juga mengucapkan terimakasih kepada pihak-pihak lainnya yang telah membantu keberlangsungan penelitian ini, terutama kepada Drs. Yusuf Suryana, M.Pd. dan Dr. Syarip Hidayat, M.Pd. selaku dosen pembimbing, hingga penelitian ini berjalan dengan lancar.

\section{DAFTAR PUSTAKA}

Choirunisa, I. (2021). Analisis Butir Soal Penilaian Tengah Semester pada Pembelajaran Tema 3 Kelas V MI Miftahul Ulum Al-Islamy Bangkalan. (pp. 1-73). Surabaya: digilib.uinsby.ac.id.

Direktorat Pendidikan Sekolah Dasar. (2016). Panduan Penilaian untuk Sekolah Dasar (SD) (Revisi). Jakarta: Kementerian Pendidikan dan Kebudayaan.

Gani, S., \& Arsyad, B. (2018). Kajian Teoritis Struktur Internal Bahasa (Fonologi, Morfologi, Sintaksis, dan Semantik). 'A Jamiy, Jurnal Bahasa Dan Sastra Arab, 07(1), 1-20.

Gimo, \& Nugrahani, F. (2019). Analisis Butir Soal Ulangan Akhir Semester (UAS) Mata Pelajaran Bahasa Indonesia Kelas XI Sekolah Menengah Kejuruan Negeri 1 Wonogiri Tahun Pelajaran 2015/2016. Stilisika: Kajian Bahasa, Sastra, Dan Pembelajarannya, 5(1), 35-46.

Hayati, N., \& Mardapi, D. (2014). Pengembangan Butir Soal Matematika SD di Kabupaten Lombok Timur sebagai Upaya dalam Pengadaan Bank Soal. Jurnal Kependidikan, 44(1), 26-38.

Isnaeni, W., Rusilowati, A., Khumaedi, M., \& Lia, R. M. (2020). Bimtek Penyusunan Tes Online Bagi Guru SD ( Program Pengabdian Pada Masyarakat Bidang Pendidikan ). 516-522. 
3646 Analisis Kesesuaian Soal Penilaian Tengah Semester IPA dengan Kaidah Penyusunan Soal pada Aspek Bahasa di Sekolah Dasar - Ima Rahmawati, Yusuf Suryana, Syarip Hidayat

DOI: https://doi.org/10.31004/edukatif.v3i6.975

Moeliono, A. M., Lapoliwa, H., Alwi, H., Sasangka, S. S. T. W., \& Sugiyono. (2017). Tata Bahasa Baku Bahasa Indonesia (Edisi ke-4). Jakarta: Badan Pengembangan dan Pembinaan Bahasa.

Mustakim, Harimansyah, G., Qodratillah, M. T., dkk. (2016). Panduan Umum Ejaan Bahasa Indonesia (Edisi ke-4). Jakarta: Badan Pengembangan dan Pembinaan Bahasa.

Nisa, S., \& Pahlevi, T. (2021). Pengembangan Instrument Penilaian HOTS Berbantuan Quizizz pada Mata Pelajaran Kearsipan SMK. EDUKATIF: Jurnal Ilmu Pendidikan, 3(5), 2146-2159.

Nurdin, R. (2019). Kompetensi Guru MIN Sabang dalam Melaksanakan Evaluasi Pembelajaran; Telaah atas Konstruksi Instrumen Penilaian Berbasis Kurikulum 2013. Jurnal Ilmiah DIDAKTIKA, 19(2), 268-286.

Prihantini, A. (2015). Master Bahasa Indonesia: Panduan Tata Bahasa Indonesia Terlengkap. Yogyakarta: PT Bentang Pustaka.

Pusat Penilaian Pendidikan. (2017). Panduan penulisan soal 2017. Jakarta: Badan Penelitian dan Pengembangan, Kementerian Pendidikan Indonesia.

Retnawati, H. (2015). Hambatan Guru Matematika Sekolah Menengah Pertama dalam Menerapkan Kurikulum Baru. Cakrawala Pendidikan, 34(3), 390-403.

Setiadi, H. (2016). Pelaksanaan Penilaian pada Kurikulum 2013. Jurnal Penelitian Dan Evaluasi Pendidikan, 20(2), 166-178.

Strauss, A., \& Corbin, J. (2003). BAB 10 Penelitian Kualitatif. In Penelitian Kualitatif (pp. 157-165). Retrieved from http://repo.iain-tulungagung.ac.id/7300/10/Bab10_Penelitian Kualitatif_3.pdf.

Sumarwati, Anindyarini, A., \& Fuady, A. (2014). Pembelajaran Kaidah Bahasa Indonesia dan Keterampilan Berbahasa Secara Terpadu dengan Pendekatan Focus on Form pada Siswa Sekolah Menegah Pertama. LITERA, 13(1), 103-113.

Suwartono, \& Hidayat, K. (2016). Kekomunikatifan Penggunaan Bahasa dalam Pembelajaran Bahasa Indonesia di SMP Negeri di Kecamatan Purwokerto Selatan. Prosiding Konferensi Nasional Ke-3, (pp.13-22). Yogyakarta: Asosiasi Program Pascasarjana Perguruan Tinggi Muhammadiyah Yogyakarta (APPPTM).

Syahriandi. (2017). Kalitas Butir Soal Ujian Ditinjau dari Segi Bahasa (Analisis Kualitatif Butir Soal). Visipena Journal, 8(1), 174-183.

Warsiman. (2020). Penggunaan Kaidah Bahasa Indonesia dalam Penulisan Skripsi Mahasiswa Fakultas Ilmu Budaya Universitas Brawijaya. ALFABETA: Jurnal Bahasa, Sastra, Dan Pembelajarannya, 3(1), 1-8.

Wuryanti, S., \& Muhardis. (2020). Studi Tentang Kemampuan Penulisan Item Tes Guru Sekolah Dasar. Dwija Cendekia: Jurnal Riset Pedagogik, 4(2), 335-348. 